\title{
The City of Pigs: a Key Passage in Plato's Republic
}

\section{Christopher Rowe}

\section{(2) OpenEdition}

\section{Journals}

Electronic version

URL: https://journals.openedition.org/philosant/281

DOI: 10.4000/philosant.281

ISSN: 2648-2789

\section{Publisher}

Éditions Vrin

\section{Printed version}

Date of publication: 1 November 2017

Number of pages: $55-71$

ISBN: 978-2-7574-1807-9

ISSN: 1634-4561

\section{Electronic reference}

Christopher Rowe, "The City of Pigs: a Key Passage in Plato's Republic", Philosophie antique [Online], 17 | 2017, Online since 01 November 2018, connection on 02 December 2022. URL: http:// journals.openedition.org/philosant/281; DOI: https://doi.org/10.4000/philosant.281

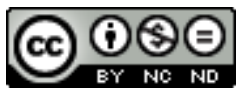

Creative Commons - Attribution-NonCommercial-NoDerivatives 4.0 International - CC BY-NC-ND 4.0 https://creativecommons.org/licenses/by-nc-nd/4.0/ 


\section{THE CITY OF PIGS : A KEY PASSAGE IN PLATO'S REPUBLIC Christopher Rowe \\ Durham University}

RÉSUMÉ. Le passage, au livre II de la République, décrivant ce que Glaucon, un des principaux interlocuteurs de Socrate, considère avec dédain comme une cité seulement digne de porcs, est en réalité central dans la stratégie globale de Platon. Le Socrate de Platon nomme de fait cette cité la cité « véritable » et « saine », et cela est vrai pour Platon comme pour Socrate - ce que démontre le présent article. La « belle cité », Callipolis, que Socrate souhaite ériger dans la suite de la République, est donc par conséquent une cité moins « véritable », et les développements concernant 1 'âme et la justice qui se fondent sur elle (au livre IV) sont, de même, des développements qui n'embrassent pas la vérité de l'âme ni de la justice. Dans leur nature vraie et essentielle, ni la cité ni 1 'âme ne sont divisées en parties, que ces parties s'opposent ou coopèrent ; et la justice non plus ne peut être absolument définie, au sens de sa nature véritable, en termes de coopération entre les parties d'une âme divisée. Si nous regardons rétrospectivement l'ensemble de la démonstration à partir du livre $\mathrm{X}$, le dernier de la République, tous ces éléments semblent être anticipés dans la description de la « cité des porcs » et sa suite immédiate.

Summary. The passage in Book II of the Republic describing what Glaucon, one of Socrates' main interlocutors, dismisses as a city fit only for pigs is in fact central for Plato's strategy in the dialogue as a whole. Plato's Socrates actually calls this city the 'true' and 'bealthy' city, and so, the essay argues, it is, for Plato as well as for Socrates. The 'beautiful city', Callipolis, that Socrates goes on to construct in much of the rest of the Republic is, by implication, less than a 'true' city, and the accounts of the soul and of justice that come to be based on it (i.e., in Book IV) are, equally, not accounts of the soul, or of justice, as they truly are. In its true and essential nature neither city nor soul is divided into parts, whether conflicting or cooperating, and neither therefore can justice ultimately be defined, i.e., in its true nature, in terms of cooperation between parts of a divided soul. As we look back from Book X, the final book of the Republic, all of these points can be seen to be prefigured in the description of the 'city of pigs' and its immediate sequel.

Philosophie antique, ${ }^{\circ} 17$ (2017), 55-71 

'City of pigs' is not the description Plato's Socrates gives to the first city he sketches in Book II of the Republic. ${ }^{1}$ Rather, it is Glaucon's description, one that Socrates shows no sign whatsoever of endorsing, ${ }^{2}$ although he can reasonably be said to provoke it by what he says about the diet and the lifestyle of the inhabitants of the city. Both diet and lifestyle would be simple: the citizens would work during the day, then feast in the evening, 'serving up noble cakes and loaves on mats of reeds or freshly washed leaves, reclining on palliasses strewn with yew and myrtle ... drinking their wine with garlands on their heads and hymns to the gods, ${ }^{3}$ and so on. Glaucon objects that the feast is 'a bit lacking in sauce.' To which Socrates responds

True... I forgot that they'll have their sauce too, and obviously things like salt and olives and cheese; and yes, they'll do as people do in the countryside, and boil up onions and greens. And I imagine we'll provide them with desserts of figs and chickpeas and beans, and they'll roast myrtle berries and acorns on the fire to a moderate accompaniment of wine... ${ }^{5}$

The mention of acorns is enough by itself to spark off Glaucon's immediate retort: 'Socrates, suppose you were putting together a city of pigs: would the fodder you'd provide for them be any different from this?' So

1. $R$. II, 369a-372d. Outline sketches of the ideas to be argued for in the present essay appeared in Rowe 2007a and ch. 5 of Rowe 2007b; see also Rowe forthcoming, in which I argue that the so-called 'city of pigs' could well have served as a model for the Politeiai of Diogenes and of Zeno, and make a detailed case against those who suppose, whether explicitly or implicitly, that Socrates' own praise for this city is not to be taken seriously.

2. In fact he plainly rejects it: see 372e2-373a7, quoted in full below.

3.372b3-7. The translations of all Republic passages in this essay are taken from Rowe 2012.

4. 3 .

5. c5-d2. The provocation to Glaucon here is clear enough: any resemblance to Mother Teresa on Socrates' part is strictly limited, and limited to this context (neither Plato's Socrates nor the real one evidently went in for so restricted a diet, or for reclining on palliasses and eating off reeds or leaves instead of properly equipped tables). 
how, Socrates asks, should he treat the inhabitants of his city? 'Just in the usual way', replies Glaucon; 'anyone who wasn't going to be in discomfort, I imagine, would have couches to recline on, tables to dine from, all the sauces and desserts they have now.' ${ }^{\prime 6}$

Fine [Socrates replies]; I see what you're saying. Evidently we're not just looking into how a city comes into being, but how a luxurious (truphosa) city does so. Well, perhaps that's no bad thing; perhaps by looking at this kind of city, too, ${ }^{7}$ we'll be able to observe how justice and injustice take root in cities. Now, I myself think the true city to be the one we were describing just now a healthy kind of city, one might say. But if the two of you want us to examine not just this city, but one that's in the grip of a fever, there's nothing to stop us doing that. It appears that there are some people who won't be satisfied with what we've offered so far, and with the kind of lifestyle we've proposed: there'll have to be couches, tables and other furniture, sauces too, perfumes, incense, prostitutes and pastries, all of them in every variety available. The things we were talking about before, basic necessities like houses, cloaks and shoes, are no longer enough; no, we're to start painting and embroidering, and to get ourselves some gold and ivory and everything like that. ${ }^{8}$

So far from being fit only for pigs, then, to Socrates his imagined city is the 'true', 'healthy' human city; the lifestyle he has sketched is one that we, as humans, should be satisfied with, and the sort of city Glaucon has in mind, the 'usual' or conventional sort,' is one that he, Socrates, regards, and by implication we should regard, as sick ('in the grip of a fever'), and in need of

6. d5-e1.

7. This 'too' (kai toiauten, sc. polin) is sometimes not noticed: Lee 1987, e.g., omits it, as does Grube as edited by Reeve ( $=$ Grube $\&$ Reeve 1997 ), and the usually unswervingly reliable Shorey, in Shorey 1935. Waterfield, in Waterfield 1993, notices the kai but misinterprets it, as Tom Griffith probably also does, in Ferrari \& Griffith 2000: 'if we look at that sort of city too, we may perhaps see the point where justice and injustice come into existence ...'- as if Socrates supposes they can only see it by looking at the new sort of city, when actually he and Adimantus had already been looking to see 'how justice and injustice take root' in the case of another city, namely the 'city of pigs'. Socrates had not only raised the same question (albeit with a different verb), in relation to this latter city, at 371e11-12 (in accordance with the strategy proposed in 368e-369b), but had begun answering it, with Adimantus, in 372a, and was answering it until Glaucon's intervention. This is of crucial importance: see further below. (Justice and injustice, in 371e11-12, are interestingly fused into a single feminine subject, as if to mark the fact - missed in Rowe 2007b, p.168-169 - that if one finds the first, ipso facto one will have found the second too.) Of course the switch to Glaucon's 'luxurious' city is required for the discovery of the Book IV definitions of justice in city and soul, but as Socrates will tell us himself (IV, 435c-d; VII, 504b), the Book IV approach does not give us the most precise or the finest view on justice. One of the chief points of the present essay will be to argue that the 'city of pigs' passage hides another view on the subject: one that Socrates prefers, just as he prefers the city Glaucon caricatures as 'piggish'.

8. 372 2-373a7.

9. 'So how should I be treating [the inhabitants of my city], Glaucon?' 'Just in the usual way (haper nomizetai).' (372d7-8) 
a cure. The cure he will go on to suggest is, of course, the imposition of philosophical rule, and all the supporting structures and institutions of Callipolis.

It is widely pointed out, and plain in any case, that this 'cure' cannot be said to take us back to the conditions of the original city - let us call it 'the first city'. This first city appears not to have, or to need, any rulers, philosophical or otherwise, or guards doubling as army and police, or indeed any hierarchy at all apart from what is implied by the division between the citizens proper and such labourers as would need to be hired to provide the brawn required to supplement citizen brains and expertise. ${ }^{10}$ In this case, it begins to look as if the purpose of the first city has been exhausted once it has fulfilled its function of identifying the basic building blocks of a city. ${ }^{11}$ But if that were to be the whole story, and Plato had no further use for this first city, it would leave us with a significant problem: if this city was always intended simply to disappear from the scene in favour of Callipolis, why would Plato have Socrates praise it to the skies, in the way that he does? It would surely be odd to prefer a city that has been restored to health from an unhealthy, feverish condition ('one that's in a feverish condition') over one that was, and stayed, healthy, especially when being 'restored to health' in the case of the former will apparently still leave it short of the bonny and unchanging health of the latter. It seems that there is more than enough justification for asking again, as I propose to do in this essay, exactly what role this city 'of pigs' plays in the overall argument of the Republic. ${ }^{12}$

That he not only favours this 'piggish', non-luxurious city, but favours it in emphatic terms, suggests that it ought not to fall out of that overall argument altogether. ${ }^{13}$ Nor in fact does Socrates forget it. Twenty-seven Stephanus pages later, he refers back directly to the very passage in which he contrasted Glaucon's preferred option with his own. ${ }^{14}$ In the course of the discussion of the musical and cultural education of the military class, from whom the rulers will ultimately be selected, Socrates at one point suggests that they have actually, without noticing, been giving 'what they were just now calling

\subsection{1d-e.}

11. See II, 569a.

12. The question was raised more than once during the session of the Société Française de Philosophie on 22 November 2014, led by Michel Narcy: see Narcy 2014. The present paper is a response, invited by M. Narcy, to the discussion at that session.

13. I.e., as 'piggish' and lacking the luxuries Glaucon expects. If Socrates had used it merely as a way to introduce the basic requirements of a city, it would have been no surprise if he failed to mention it explicitly again; it is the fact that he says it is his preferred city (lifestyle and all) that would make its disappearance from the argument problematic.

14. I.e., at II, 372e2-373a7. 
a luxurious city'15 a proper cleansing or purification (diakathairein). This refers in the first instance to the measure he and Glaucon have just agreed to, outlawing any musical instruments other than the (allegedly 'purer') lyre and cithara, with panpipes for rustics. ${ }^{16} \mathrm{He}$ then follows this suggestion, however, by proposing that they should 'go on and clean up ('purify', kathairein) the bits that are left' (ta loipa); and while these 'bits that are left' are, immediately, other aspects of music, the proposal can also be taken more broadly, that is, as signalling Socrates' intention that Callipolis as a whole should ultimately be as 'clean' as possible. Since a 'luxurious' city was originally also conceived of as a sick, 'feverish' one, 'cleansing' it will presumably also be a matter of curing it of its fever; and since it was 'feverish' by comparison with the first, 'piggish', city, it is also reasonable to suppose that 'cleansing' and 'curing' it so far as possible will amount to making it as like to that first city as possible. It cannot be completely cleansed or cured, and so actually become that first city; it will still be host to the 'luxuries' that make it 'feverish', even if they are denied to the guards and rulers. To that extent it must always be a sick rather than a truly healthy city. But that is why it needs guards, and rulers - and especially philosophical rulers, ${ }^{17}$ insofar as it is philosophy that will provide the insight required for the maintenance of the city's institutions: the maintenance, above all, of its educational system, which produces guards immune to the allure of gold, silver, and the rest, so rendering them saviours both of themselves and of the city. ${ }^{18}$ In short, it seems that Callipolis is as close as it can be to Socrates' first city as it can be while complying with Glaucon's requirement that it have all the 'comforts' ${ }^{\prime 19}$ be thinks inseparable from the idea of a city.

There are two prima facie objections to this interpretation. The first of these is that, surely, 'as close as possible' will not be close at all, given that the Callipolitan hierarchy, which the Socratic city lacks, is actually Callipolis' most distinctive feature. The second and (apparently) just as obvious objection is that the educational programme that seems to do the heavy lifting with the 'cleansing' or 'purification' of the second city ${ }^{20}$ is specifically designed for the guards, and the eventual rulers, not for the population at large; the majority of the citizens will, by implication, be left to their own devices, and to the pleasures and luxuries denied to the ruling and military classes. So the cleansing is not of the city, just of one sub-group, among the

15.399e5: hen arti truphan ephamen polin.

16. III, 399d-e.

17. V, $473 \mathrm{c}$-e.

18. III, $417 \mathrm{a} 6$.

19. I.e., those things that allegedly contribute to the absence of talaiporia for a person: II, 372d9.

20. I.e., the city that immediately succeeds the 'city of pigs', prior to its 'cleansing'. 
citizens, however important a sub-group it may be.

Both of these objections, however, can readily be met. In response to the first, we should notice that while Callipolis looks, and is, very different from Socrates' first city, it also shares with it what is - from the perspective of the overall argument of Books II-IV, and of its main purpose of providing an account of justice - the single most important feature of all. The justice of Callipolis will turn out to be a matter of 'each single individual's doing the job that is his, and not meddling in what should be done by others'. So Socrates will propose, ${ }^{21}$ and Glaucon will agree. But the first city actually starts from a version of this principle. ${ }^{22}$ It is also in the course of the first city passage that Socrates establishes and justifies the principle itself ${ }^{23}$ (thus making the passage foundational for the rest of II-IV). The description of the first city even comes within a whisker of anticipating the Book IV account of justice in the city, by identifying it, as Book IV does, with the idea 'one citizen, one job' itself. ${ }^{24}$ In short, until it is rudely interrupted by Glaucon's objection, that Socrates is treating the city's inhabitants no better

\section{IV, 433d3-4.}

22. 369b7-c3: 'Cities come into existence, I imagine, because in fact none of us is selfsufficient; taken by ourselves, each one of us is deficient in many respects... Thus it will be because one person recruits another to fill this or that need, and another another, and so on, and because our needs are many, that we gather many people together to live in a single location as partners and helpers, calling this shared habitation a "city"' (with a pun on polloi/ polis).

23. 'Then one person shares something with another, if he does, or takes his share from another, because he thinks doing so is better for himself?' (369c6-7) It will be better if functions are distributed between different people, because (a) 'each of us is not born exactly like everybody else, but with different natural capacities' (370b1-2); (b) any individual will be 'more effective [i.e., get more done?] when he ... confines himself to one area' rather than spreading himself over more than one (b5-7); (c) he will also be better able to catch the right moment (b11-c2).

24. This is in $371 \mathrm{e} 11 \mathrm{ff} .:$ 'So where on earth shall we find [the city's] justice or injustice? Of those aspects of it that we've examined, which is the one it will have originated with?' 'I can't think, Socrates,' said Adimantus, 'unless perhaps it's to be found somehow in the mutual need all these categories of people have for each other.' 'Perhaps you're right,' I said; 'we must look and see at once - no holding back. So first of all let's see how our people will occupy their time, now that they're provided for in the way we've described - presumably they'll spend their time producing food, wine, cloaks and shoes. They'll build houses, and in summer they'll work away mostly naked and shoeless, while in the winter they'll wear whatever clothes and shoes they need to protect them.' (Then follows the description of the inhabitants' eating, sleeping and leisure arrangements that provokes Glaucon into his reference to pigs, which causes Socrates to break off his proposed examination of Adimantus' suggestion. On the interpretation I propose, without Glaucon's intervention Socrates could have moved directly to an account of justice in the city in terms of the formula 'one citizen, one job', although with no hierarchical divisions among the relevant inhabitants of the first city such an account would have looked very different from the account ultimately reached in Book IV, as would any analogical account of justice in the soul: see below.) 
than pigs, it seems that the description of the first city is itself well on the way to filling the role that will ultimately be filled by its far longer sequel, the account of the 'City Beautiful', Callipolis. If so, then the puzzle is no longer about the function of the first city in the overall argument, but rather about the function, in that argument, of Callipolis itself: why does Socrates/Plato shift the search for justice from the first city to the much larger and more complex construction represented by Callipolis? And this new ${ }^{25}$ puzzle is all the greater for the fact that the distinctive hierarchical structure of Callipolis at least initially derives from the introduction of luxuries that a city, on Socrates' account, not only can perfectly well do without but is seriously harmed (rendered 'feverish') by admitting. Allowing for the 'sauce' Glaucon wants added to the life of the city means vastly increased numbers of inhabitants, so a larger territory, so an army ${ }^{26}$ - the guards, who according to the founding principle necessarily constitute a separate group of people - and so also a ruling class equipped to ensure that the whole city, and especially the educational system, continues in the right direction. ${ }^{27}$ Looked at in this way, the hierarchical structure of Callipolis is required precisely in order to allow it to approximate to the simplicity and unity of Socrates' original city.

This is made even clearer by the obvious response to the second of the two objections raised above, namely that the process of 'cleansing' extends only to the guards, not to the rest of the population (and so not to the city as a whole, as I supposed $\left.{ }^{28}\right)$. Why, one may ask, should this matter? Why should we presume that the citizens of Callipolis other than the rulers and the guards - i.e., mostly, those involved in seeing to the city's material needs - will turn to pleasure and luxury? The underlying principle of the City Beautiful is that 'each individual should practice the single role to which his nature is most suited, among those relevant to the city', ${ }^{29}$ and this, as Socrates makes clear, will rule out anything that interferes with that role. He chooses

25. 'New', at any rate, in terms of the argument of the present essay. Many modern interpreters have been inclined to regard the shift in question as a matter of Plato's (and his Socrates') moving on from a sort of impossible, rustic dream - one that even Socrates (surely!) cannot take seriously! - to hard analysis. Such interpreters have failed to discern the core point that hides beneath Socrates' provocation to Glaucon and his like, and is not withdrawn at any point: that the very luxuries they take for granted make a city, and by implication its citizens, unhealthy and in need of a 'cure'.

26. II, 373a-374a.

27. As Republic V shows, Plato thinks philosophical rule justified and necessary in any case (that is, apart from any special reasons deriving from the context of the argument of the Republic itself). But as we can see from the Statesman and the Laws, government by philosophers need not mean making kings and queens into philosophers; it can also be realized in the form of a philosophical adviser, or philosophical legislators.

28. See my comments, above, on ta loipa at III, 399e7.

29. III, 433a5-6 (this is 'what we laid down, I believe, and frequently asserted, if you recall', a4). 
to express this point by reference to the very sort of luxuries that are denied to the rulers and guards, and that Glaucon thought 'usual' - the sort that Adimantus too thinks are needed to make people happy. Adimantus has claimed that Socrates is depriving the guards of everything that is thought (nomizetai) to be required for happiness, ${ }^{30}$ like gold and silver; to which Socrates replies that

you shouldn't force us to attach a kind of happiness to the guards that will make them anything but guards. We could if we wanted give our farmers the same treatment - dress them up in elaborate robes, put gold round their necks and tell them to work the land when they felt like it. We could have the potters reclining on couches, left to right before the fire, drinking and feasting to their hearts' content, their wheels to one side to use just so much as they wish. We could give everybody else the same sorts of blessings, and make the whole city happy that way. But don't advise us to adopt that course, because if we do as you say, farmers won't be farmers, potters won't be potters, and in general all those types needed to make up a city will tend to merge into one another. Now if this happens with most of them it doesn't matter so much: if shoe-stitchers are corrupted and turn bad, so that they only pretend to be good at stitching shoes, a city ${ }^{31}$ has nothing to fear from that. But if those who guard the laws and the city are not what they seem to be, you see for yourself that it spells the complete ruin of any city; equally, excellence in those who guard us is the sole measure of good government and of happiness. So if we, for our part, are making our guards true guards, who least of all threaten harm to the city, whereas that critic of ours just wants to make some collection of farmers happy, as if they were feasters at a communal banquet, not members of a city - well, it's something else he's talking about, not a city. ${ }^{32}$

Of course potters, farmers and shoemakers in Callipolis won't 'recline on couches, left to right..., drinking and feasting to their hearts' content', since such things are anyway mostly the preserve of the leisured class, i.e., the likes of 'that critic of ours', i.e., Adimantus, ${ }^{33}$ or his brother Glaucon. When Socrates says that this critic 'just wants to make some collection of farmers happy, as if they were feasters at a communal banquet', part of his point is that such a conception of happiness is worthy only of farmers - or potters, or shoemakers, or anyone else lacking a proper education. ${ }^{34}$ In other words, Adimantus and Glaucon and their sort ought to know better; as co-legis-

30. IV, 419e9-10.

31. Or should this be 'the city', despite the absence of the definite article in the Greek (421a6)? It would certainly harm the first city if its members stopped cooperating, and doing what they are meant to do. But then they won't have 'elaborate robes, ... gold', etc. to corrupt them, any more than the Callipolitan guards will.

32. $420 \mathrm{~d} 6-421 \mathrm{~b} 4$.

33. Adimantus it was who made the point being criticized.

34. That is, farmers, potters and shoemakers who grow up in any ordinary ('usual') city? 
lators for the new city, the brothers need to recognise that the leisured life they think 'usual' is no more suitable or happy-making for those whose role it is to fight for the city - as they have done, with distinction ${ }^{35}$ - than it would be for those destined to be farmers or potters or shoemakers. Indeed, as Socrates says, it is considerably less suitable for the military class, when judged in terms of the damage done to the city. But what matters for present purposes is that the passage just cited clearly shows that the producers of Callipolis are expected to stick to their roles as much as the guards and the rulers are expected to stick to theirs, on pain of their ceasing to be proper parts of a city. ${ }^{36}$ But that we surely know in any case, if Callipolis is a just city (as it is claimed to be), and if justice in the city is (as it will turn out to be) a matter of 'each single individual ... doing the job that is his own .... The producers will still apparently be subject to 'the many and various ordinary desires, and pleasures and pains', the sort that 'you'll find especially in children and women and slaves, as well as in the ordinary, inferior men who make up the majority of those who are called free, ${ }^{37}$ but these, according to Socrates' account of moderation (sophrosune) in the city, will somehow ${ }^{38}$ be 'controlled ... by the desires and the wisdom that reside in those who are fewer and superior.' ${ }^{9}$ This is not to say that the uneducated producers will necessarily go astray, or even be tempted to do so, but the city will have the power and the means to deal with them if they do. This, presumably, may count as 'cleansing' by other means.

So, to return to my 'puzzle': if the first city passage (369a-372d) already provides the core of what is required for the account of justice in the city, why then does Socrates agree to relocate the search for justice to a different city, under different conditions - and (we can now add) conditions that will at best only allow an approximation to justice as it might be discovered in the city that is being left behind? Given that the whole (official) purpose of the inquiry is to find an appropriate account of justice in the soul, it would hardly be far-fetched to suppose that the explanation of this move has something to do with the sort of account of justice in the soul that is derivable, by the agreed method of analogy, ${ }^{40}$ from that of justice in the city in the two cases;

35. See I, 367e-368a.

36. This is a partial paraphrase of the difficult lines 421b2-3, the translation of which above makes the best of the text printed in Simon Slings's Oxford text.

37. IV, 439b9-c3.

38. Presumably, through laws established by the rulers and enforced by the guards in their internal policing role.

39. 431c10-d2; cf. IX, 590d4-6.

40. 'The agreed method of analogy': see 368c-369b. 
and plainly, the account of justice in the soul that is derivable, and derived, in this way in the case of Callipolis is not so derivable in the case of the first city. If there is no hierarchy among the inhabitants of the first city, neither can there be any among the parts of the souls of its citizens. ${ }^{41}$ Indeed, insofar as the division of the soul into parts in the Republic is established on the basis that the soul can be in conflict with itself, the absence even of potential conflict between the inhabitants of the first city ${ }^{42}$ makes it unlikely that a soul constructed by analogy with them ${ }^{43}$ would have parts at all; instead, it would be host to a collection of different aspects, all contributing harmoniously to the whole.

These claims clearly need fleshing out. Talking about Callipolis, Socrates observes that there must be 'the same kinds and dispositions [i.e., the wisdom-loving, the spirited, and the 'money-loving]' - in us as there are in the city':

I don't imagine they could have got there from anywhere else. It would be ridiculous to suppose that spiritedness in cities doesn't originate in individual citizens - who do actually get the credit for it, as for example in Thrace or Scythia, or pretty generally in the northern regions; and there could hardly be any other source for the love of learning that would be associated especially with our region, or for the love of money one would attribute most of all to the Phoenicians and the inhabitants of Egypt. ${ }^{44}$

Just as the spiritedness, love of wisdom and love of money that supposedly characterize different races must derive from the possession of the same characteristics by their members, so the characteristics of the three different 'kinds of natures' 45 that form the hierarchy of Callipolis, or of any city like it, ${ }^{46}$ must derive from their possession by individuals with those 'kinds of natures. ${ }^{47}$ The analogy with different races makes it look, at first sight, as if each of the three dispositions, spiritedness, love of wisdom and love of money are being assigned separately to the three Callipolitan classes. But this of course is not the case: the members of all three classes must possess all

41. '[A] just man won't differ at all from a just city in respect of the form itself, justice, that they have in them' (IV, 435b1-2). See further below.

42. 'Even of potential conflict': the first city, after all, is supposed to contain all those elements that make up a city; cooperation is one of those elements, discord is not.

43. That Socrates himself does not apply the analogy in this way may be put down in the first instance to the fact that his account of the first city is cut short. But see further below.

44.IV, 435d9-436a3.

45. $435 \mathrm{~b} 5$ gene phuseon.

46. Callipolis, after all, is supposed to be a model for the reform (i.e., the cleansing) of cities in general; a city will - if Callipolis is the model - not count as reformed or cleansed unless it possesses the same ordered hierarchy.

47. Cf. Narcy 2014 p.18: 'Ce que fait apparaître la façon dont procède Socrate pour définir la justice, c'est qu'entre l'âme tripartite et la cité tripartite il y a plus qu'une analogie: une corrélation.' 
three 'kinds and dispositions' together (just to different degrees), or else the job of selection would be divinely easy, and the task of educating the citizens so much simpler. And this is what gives rise to the division of the soul into three parts or elements. Glaucon has no difficulty in seeing that the city's qualities must derive from its citizens.' 'But', Socrates continues,

what is difficult to see is whether we perform each of these three activities with the same thing, or with three things, one for each - do we learn with one element in us, feel anger with another and use some third element for desiring the pleasures of nourishment, procreation and everything related to these? Or in each of these cases, as we set ourselves in motion, are we acting with the whole soul? That's the question it will be difficult to settle properly. ${ }^{48}$

As I have said, and as is well known, Socrates goes on to settle it by arguing from the possibility of conflict within the soul, between appetite and reason, and spirit and appetite. Now by the principle that the character of a whole with parts (a city, for example) must derive from the character of the parts, the apparently unqualified unity of the first city ought to derive from a similar unity in the souls of its inhabitants. In relation to the first city, then, the argument for the division of the soul will have no application. It can work, insofar as it works at all, in the context of Callipolis because the souls of the citizens, while ordered, and just insofar as they are properly ordered, are only contingently so, as a result either of education and training or, in the case of the producers, of control by the guards; internal conflict remains always a possibility. Indeed, in the case of the producers, their desires may be out of kilter with their beliefs even if they do not act on those desires, and this is all that is required by the argument that claims to separate off the rational from the appetitive part of the soul. ${ }^{49}$ The citizens of the first city, too, will think, get angry, be thirsty, and so on, and no doubt it will be appropriate to think of these as distinct soul-functions, ${ }^{50}$ but insofar as those functions will never be in conflict (given that the soul in each case is as unified as the city is), there will be every reason to think of them as being performed 'with the same thing' rather than 'with three things [or elements], one for each'; it is 'the whole soul' that acts in each case. ${ }^{51}$

This chimes with a passage in the Sophist, in which Socrates suggests

48. 436a8-b4.

49. See 439c.

50. Represented, perhaps, on the city side of the analogy, by the non-citizen labourers (see text to $n .10$ above)?

51. The terms used here are of course borrowed from 436a8-b4, cited just above. There might be other, different ways of describing the relationship between different aspects of a partless soul, but this is the one Socrates offers us. 'The whole soul', I suppose, would include its appetitive aspects (which are no less aspects of the soul than the labourers are of the city, being its pleroma, 'making up its complement', II, 371e6, even though '[their] share in intellectual qualities is not quite enough for it to be worth making them partners', d10-e1). 
that internal conflicts typically occur in souls of people that are in poor condition' (phlauros echontes). 'Well now', he says, 'in a soul, when people are in poor condition, don't we observe beliefs disagreeing with desires, anger with pleasures, reason with pains, indeed all of these with each other?' (Sophist 228b2-4). ${ }^{52}$ In the Republic the guards and the rulers, at least, are not presently in poor condition, but if things go wrong for the city they might be - just like the rest of us: the parts of soul argument as a whole is framed in terms of common experience. ${ }^{53}$ But that does not mean that human souls have to be like that, or in other words that that is the natural human condition. One is reminded, in this context, of the striking passage in Book X where after offering an argument for the immortality of the soul, Socrates offers the following commentary:

It's not easy for something to be timeless, if it's a composite of many elements and they haven't been put together in the most beautiful way, which is what appeared to us to be the case with the soul [sc. (especially) in Book IV]... Well, that the soul is immortal will follow both from our argument just now, and from other arguments; but as for seeing the kind of thing it truly is, one mustn't look at it as we are looking at it now, crippled by its association with the body and other things that harm it. Rather, we must use rational reflection to examine it properly, as it is when it's purified from such things, and if we do so sufficiently well, we will find it to be something far more beautiful, and gain a far clearer insight into things like justice and injustice, and everything else we have talked about on the present occasion. As it is, what we have said about it describes truly enough the way it presently appears; yet to have viewed it in that condition makes us like people who see the sea-dwelling Glaucus: they see him, but can't any longer easily make out his original nature - the old parts of his body have been broken off or been worn away by the waves, mutilated out of all recognition, while others have attached themselves in the form of shells and seaweed and rocks, so that he resembles any kind of beast more than he does his old natural self. That is the condition in which we're seeing the soul, too, beset by countless sources of harm. But we must turn our gaze elsewhere, Glaucon... [to] the soul's love of wisdom - reflecting on the things it touches on, the sorts of company it strives for, akin as it is to the divine and immortal, that which always is, and what it might become if the whole of it applied itself to such things, and this impulse lifted it clean out of the sea in which it is now ... Then one would see whether its true nature is to contain many kinds within it, or only one [or

52. The translation is from Rowe 2015; in a footnote, I comment 'Such internal "disagreement" in the soul is treated, in Book IV of the Republic, as the basis of an argument for dividing the soul into three forms or parts; if that argument were starting from what Socrates says here in the Sophist, would the division only apply in the case of souls "in poor condition"?

53. Beginning with that observation of Socrates' at $435 \mathrm{~d} 9-\mathrm{e} 2$, that 'there are the same kinds and dispositions in us as individuals (en hekastoi ... hemon) as there are in the city'. 
'whether it is complex (polueides) or uniform (monoeides)], or exactly how it may be... ${ }^{54}$

It cannot be said that love of wisdom is the most prominent characteristic of the first city's inhabitants. In fact, for all that Socrates tells us about them, one might suppose that they have few if any intellectual interests at all. The immediate purpose of citing this passage here is twofold: first, that it provides clear confirmation of Socrates' highly qualified attitude towards the Book IV analysis of the soul; and second, that it provides what one might call a conveniently commentated example of what he may have in mind when he calls some $x$ a 'true' $x$, as he calls his first city the 'true' city. And the description of Glaucus fits well enough, mutatis mutandis, with the city that succeeds this 'true' one: 'the old parts of his body ... broken off or ... worn away by the waves, mutilated out of all recognition', to be replaced by 'others in the form of shells and seaweed and rocks, so that he resembles any kind of beast more than he does his old natural self'. The idea of parts being replaced decidedly does not fit, but then, given that Socrates will immediately raise the possibility that the true soul might be monoeides, contain only a single kind, it is not relevant to the analogy in its original application either. The overlay of 'shells and seaweed and rocks' is represented, in the case of the second city of Book II, not only by the things that Glaucon insists on adding to the first (and are so added in real life: 'couches, tables and other furniture, sauces too, perfumes, incense, prostitutes and pastries, all of them in every variety available... painting and embroidery,... gold and ivory and everything like that'), ${ }^{55}$ but also the extra territory to accommodate the additional inhabitants these will entail, and then the army that will be needed to acquire that extra territory.

According to the majority of modern interpreters, the Republic (specifically, Book IV) marks the point at which Plato abandoned the distinctive Socratic psychology that is entailed by his intellectualist theory of action. ${ }^{56}$ If the argument advanced in the preceding sections is correct, such an interpretation becomes unviable. The Plato of the Republic does not abandon the Socratic view of the soul as a naturally unified whole; rather, it combines that view with another, of the soul as it is when it has come to be in poor condition', i.e., as divided, with its 'beliefs disagreeing with desires, anger with pleasures, reason with pains, indeed all of these with each other' (to borrow the

54.R. X, 611b5-612a3.

55. II, 373a2-7.

56. Cf. Narcy 2014 p.18: 'Il est classique de voir dans cette tripartition de l'âme le moment où Platon se détourne de l'intellectualisme socratique vers une psychologie plus complexe, et plus réaliste'. 
language of the Sophist). This is soul as implicitly introduced by, and resembling, the 'feverish' city, before the imposition of philosophical control, ${ }^{57}$ and as such, if the soul-city analogy is to hold, it will itself be a product of the same ('luxurious') conditions that cause fever in the city. My interpretation here intersects nicely with Michel Narcy's:

Pas de justice, donc, dans la cité qui n'est pas réformée, ${ }^{58}$ dans cette cité en proie à la fièvre et couverte de furoncles. Rappelons-nous que dans cette cité, le thumoeides n'est à l'origine que l'un de ces furoncles: c'est le tempérament de ces hommes introduits dans la cité pour lui permettre les conquêtes dont elle a besoin et empêcher les empiètements dont elle est menacée. Si l'on prend à la lettre l'analogie âme-cité, il faut en conclure que le thumos, lui aussi, s'introduit dans l'âme à la faveur des désirs qui, en elle, outrepassent les besoins naturels. Aussi longtemps que les habitants de la cité naturelle [i.e., the first city] n'ont pas plus de désirs que de besoins, il est probable, si l'analogie homme-cité est exacte, qu'ils n'ont pas de thumos. En d'autres termes, l'âme n'est pas plus tripartite de nature que ne l'est la cité, et si l'on réfléchit que, dans la cité réformée qu'imagine Socrate, les dirigeants sont issus d'une sélection parmi les gardiens, il est loisible de penser que la raison, homologue dans l'âme des dirigeants dans la cité, suppose elle aussi l'éducation du thumos, sa transformation, d'impétuosité potentiellement violente, en force morale. L'âme tripartite paraît ainsi tout aussi artificielle, aussi éloignée en tout cas de sa nature première, que la cité juste est éloignée de la cité naturellement saine, la vraie cité.

This differs from my own conclusions in just two respects. First, while there is a sense in which the 'reformed' tripartite soul may be artificial (it is, at any rate, the product of an education imposed from the outside), the unreformed tripartite soul - soul as it surfaces, briefly, in and among the arguments for tripartition itself - is on my interpretation rather the product of decay, and of neglect, especially of its capacity for reason. Second, to infer from the city-soul analogy, in the way Narcy suggests, that the inhabitants of the first city lack thumos is surely (I say) to push the analogy too far. If the thumoeides appears in a negative light in the unreformed city and the corresponding soul, it evidently has positive aspects to it too, which do not depend on education and which Socrates might surely want to attribute to a soul in good as well as to one in bad condition: thus for example in Book IV thumos turns out to be 'a natural ally for the reasoning element, unless it is corrupted by a bad upbringing. ${ }^{59}$ I would prefer to say that thumos only becomes treated as a separate part of the soul, or treatable as if it were a separate part, in the

57. Michel Narcy (Narcy 2014 p.6, referring to Adam 1902) notes that Callipolis is, strictly, Socrates' third city, the second being the unreformed, 'luxurious' city insisted on by Glaucon - in which, by Socrates' lights, there will be no justice (Narcy 2014 p.19).

58. I.e., the second city (see preceding note).

59. 441a2-3. 
context of the second city and its reformed counterpart, Callipolis. Similarly with reason, and with appetite. ${ }^{60}$ The first city, so peremptorily dismissed by Glaucon - and by some modern interpreters - as fit only for pigs, offers a picture of a city, and by implication of a soul, that possesses the unity appropriate to a 'true' city and to the soul as it 'truly' is. The passage that introduces that city thus fully deserves to be described as 'key', as in the title of this essay, for it quietly ${ }^{61}$ tells us how to read the following five and a half books: as an account of a beautiful city whose beauty is nevertheless qualified, insofar as it only approximates to the beauty of the city in nature. ${ }^{62}$ Not only that, but even more quietly it gives us the first of several hints that despite the arguments of Book IV we still need to consider both 'whether [the soul's] true nature is to contain many kinds within it, or only one, or exactly how it may be, ${ }^{63}$ and, in the same connection, whether the account of justice offered, there in Book IV, genuinely captures the true nature of justice. ${ }^{64}$

60. On appetite, see notes 50 and 51 above.

61. Plato's 'quietness' about his strategy here I explain by reference to the kind of audience he means to address in the first instance - an audience (I propose) that would include the likes of Glaucon, whose intervention sparks Socrates' shift from first to second and third cities. See Rowe 2016.

62. See Narcy 2014, p.8: 'la société décrite par Socrate [i.e. the first] est une société qui doit tout à la nature ... Il s'agit toujours d'une société qui vit à l'état de nature: nous sommes aux antipodes de Rousseau, aux antipodes aussi de Protagoras, mais ce que nous lisons ici, c'est la version socratico-platonicienne de l'état de nature.'

63. X, 612a3-4 (cited above).

64. This is not to deny that what is described in Book IV is a sort of justice. On degrees of justice and the other virtues in the Republic, see Rowe 2013; also, importantly, Sedley 2013. Sedley recognises 'the recurrence, at the heart of the Republic, of Socratic intellectualism', while at the same time taking a rather different view from mine on the question 'how Socratic intellectualism can [Sedley's own italics] remain true [i.e., for Plato], at a point in [his] work where tripartition gives every appearance of having superseded it' (p.85). 


\section{BIBLIOGRAPHY}

Adam, J. 1902 (éd.) : The Republic of Plato, edited, with critical notes, commentary and appendices, Cambridge, 1902.

Ferrari, G. R. F. \& T. Griffith 2000 (éd. et trad.) : Plato, The Republic, Cambridge, 2000 (Cambridge Texts in the History of Political Thought).

Grube, G. M. A. \& C. D. C. ReEve 1997 (trad.) : Plato, Republic, dans J. M. Cooper (éd.) et al., Plato, Complete Works, Indianapolis, 1997, p. 971-1223.

LeE, F. D. P. (trad.) 1987 : Plato, The Republic, with an introduction by M. Lane, London, 1987 (Penguin Classics).

NARCY, M. 2014 : «Cité naturelle et cité juste dans la République de Platon », Bulletin de la Société française de Philosophie, 108/4 (2014), p. 5-40.

Rowe, C. J. 2007a : « The Place of the Republic in Plato's Political Thought », dans G. R. F. Ferrari (éd.), The Cambridge Companion to Plato's Republic, Cambridge, 2007, p. 27-54 (Cambridge Companions to Philosophy).

- 2007b : Plato and the Art of Philosophical Writing, Cambridge, 2007.

- 2012 (trad.) : Plato, Republic, translated with an introduction and notes, London, 2012 (Penguin Classics).

- 2013 : « On justice and the other virtues in the Republic : whose Justice, whose Virtues ? », dans N. Notomi \& L. Brisson (éd.), Dialogues on Plato's Politeia (Republic) : selected papers from the Ninth Symposium Platonicum, Sankt Augustin, 2013, p. $49-59$ (International Plato Studies, 31).

- 2015 (trad.) : Plato, Theaetetus and Sophist, Cambridge, 2015 (Cambridge Texts in the History of Philosophy).

- 2016 : «Plato's Rhetorical Strategies : writing for philosophers, writing for non-philosophers », dans I. Männlein-Robert, W. Rother, S. Schorn, C. Tarnau (éd.), Philosophus Orator: Rhetorische Strategien und Strukturen in philosophischer Literatur : Michael Erler zum 60. Geburtstag, Basel, 2016, p. 85-108 (Schwabe interdisziplinär, 10).

— forthcoming : «The Four Republics », dans S. Husson, J. Lemaire (éd.), Les trois républiques, Platon, Diogène, Zénon, Paris, Vrin, forthcoming (Histoire de la philosophie).

SEDLEY, D. N. 2013 : « Socratic intellectualism in the Republic's central digression », dans G. Boys-Stones, D. El Murr, C. Gill (éd.), The Platonic Art of Philosophy, Cambridge, 2013, p. 70-89.

Shorey, P. (trad.) 1935-1956 : Plato, The Republic, vol. 1 et 2, Cambridge (Mass.)/ Harvard/London, 1935-1956 (Loeb Classical Library, 237 et 276).

Slings, S. R. 2003 (éd.) : Plato, Platonis Rempublicam, recognovit brevique adnotatione critica instruxit S. R. Slings, New-York, 2003 (Scriptorum Classicorum Bibliotheca Oxoniensis).

Waterfield, R. 1993 (trad.) : Plato, Republic, Oxford, 1993 (Oxford World's Classics). 